\title{
EFFECT OF ENVIRONMENTAL TEMPERATURES ON PRODUCTION AND BREAD CHARACTERISTICS FOR BREAD WHEAT CULTIVARS \\ I. EFFECT OF ENVIRONMENTAL TEMPERATURES ON YIELD AND ITS COMPONENTS
}

Abo El-Naga, M. M. ${ }^{1}$ and Hoda, M. M. El-Gharbawy ${ }^{2}$

1) Food Technology Research Institute, Agricultural Research Center

2) Wheat Research Department, Field Crops Research Institute, Agricultural Research Center.

\begin{abstract}
Four bread wheat cultivars, namely; Sakha 93, Misr1, Gemmeiza 9 and Sids 12 were gown in two different environments in Wheat Research Department, Sakha station (North Egypt) and Asouyt station (South Egypt) during two growing seasons; 2010/2011 and 2011/2012. Data were recorded for yield and its components (grain yield, no. of kernels/spikes, no. of spikes $/ \mathrm{m}^{2}$ and kernels weight) as well as some morphological characters (days to heading, days to maturity, grain filling period, grain filling rate and plant height). The results appeared that Sids 12 and Misr1 were the highest cultivars in grain yield at Asouyt station (South Egypt), while Misr1 was the greatest in grain yield at Sakha station (North Egypt). Grain yield, plant height, no. of kernels/spikes, no. of spike $/ \mathrm{m}^{2}$ and days to maturity were decreased at South Egypt than at Sakha station. Therefore, the current study concluded that it is possible to utilize wheat yield and its components as a good indicator to estimate the impact of heat on the wheat productivity, tolerant and characteristics.

Keywords: Bread wheat, environmental temperatures, yield and its components
\end{abstract}

\section{INTRODUCTION}

Wheat (Triticum aestivum, L) is one of the main cereal crops, cultivated the demands of the increasing population for human feeding. Increasing grain yield of cereal crops is considered one of the more important national goals in Egypt to face the needs of increment of Egyptian population. The total production of wheat in Egypt in 2011/2012 season was estimated by 8.8 million tons resulted from 3.1 million faddan with an average of 18.7 ardab/faddan (The Agricultural Economic and Statistics Department, Ministry of Agriculture, 2011). In most wheat growing regions especially in the Mediterranean climate, grain filling is subjected to several physical and biotic stresses. Grain filling often occurs, when temperatures are increasing and moisture supply is decreasing (Mohammadi et al., 2009). Short heat stresses $\left(\geq 35^{\circ} \mathrm{C}\right)$ in the post-anthesis period can significantly reduce grain weight in wheat and barley (Wardlaw and Wrigley, 1994) and, also, decrease grain quality (Savin et al., 1996). Terminal heat is a major abiotic stress affecting yield in wheat. Under heat stress, the photosynthetic process is affected especially during grain filling stage when demand for assimilates is the greatest (Kumari et al., 2007). Temperature fluctuations during grain filling cause deviations from expected dough properties (Blumenthal et al. 1991). 
The rise in daily average temperature, up to about $30^{\circ} \mathrm{C}$, increased dough strength, while temperatures above this threshold value $\left(35-40^{\circ} \mathrm{C}\right)$, even for periods of only few days, tended to decrease dough strength (Corbellini et al., 1997). Wheat shows a highly significant stress stability genotype by environment interaction (GxE) (Reynolds et al., 2002). The protein content in flour significantly increases with bread wheat as the result of the heat stress (Balla and Veisz, 2007 and Labuschange et al., 2009). The deterioration in the dough quality could be attributed to the decline in the glutenin-to-gliadin ratio and in the percentage of very large glutenin polymers in response to the high temperature (Bencze et al., 2004; Balla and Veisz, 2007 and Balla et al., 2011).

The objectives of this study were to evaluate the yield and its components and quality of some wheat varieties under two successive deferent environments, i.e., North Egypt Sakha station (Normal) and South Egypt Asouyt station (heat environment) conditions.

\section{MATERIALS AND METHODS}

Four bread wheat cultivars, Sakha 93, Misr1, Gemmeiza 9 and Sids 12 , were grown in this experiment during two seasons (2010/2011 and 2011/2012) in wheat Research Department at two locations, Sakha and Asouyt stations.

Table (1): Max. and Min. temperature $\left({ }^{\circ} \mathrm{C}\right)$ at Sakha and Asyout stations in two growing season (2010/2011 and 2011/2012).

\begin{tabular}{|c|c|c|c|c|c|c|c|}
\hline & $\begin{array}{l}\text { Temp. } \\
\text { mean }\end{array}$ & $\begin{array}{l}\text { Temp. } \\
\text { mean }\end{array}$ & Relative & & $\begin{array}{l}\text { Temp. } \\
\text { mean }\end{array}$ & $\begin{array}{l}\text { Temp. } \\
\text { mean }\end{array}$ & Relative \\
\hline Month & $\max$. & $\min .\left({ }^{\circ} \mathbf{C}\right)$ & $\begin{array}{c}\text { humidity } \\
(\%)\end{array}$ & Month & $\begin{array}{l}\max . \\
\left({ }^{\circ} \mathrm{C}\right)\end{array}$ & $\min .\left({ }^{\circ} \mathrm{C}\right)$ & humidity (\%) \\
\hline & \multicolumn{3}{|c|}{ Sakha station 2011} & & \multicolumn{3}{|c|}{ Asyout station 2011} \\
\hline \begin{tabular}{|l|} 
January \\
\end{tabular} & 24.1 & 7.8 & 51.0 & January & 26.3 & 7.6 & 47.0 \\
\hline February & 26.9 & 10.6 & 42.0 & February & 29.1 & 9.6 & 38.0 \\
\hline March & 29.5 & 13.4 & 42 & March & 30.7 & 12.9 & 43 \\
\hline April & 32.8 & 16.5 & 34.0 & April & 34.5 & 16.5 & 35.0 \\
\hline \multirow[t]{2}{*}{ May } & 35.6 & 19.2 & 31.0 & May & 36.4 & 18.2 & 31.0 \\
\hline & \multicolumn{3}{|c|}{ Sakha station 2012} & & \multicolumn{3}{|c|}{ Asyout station 2012} \\
\hline \begin{tabular}{|l} 
January \\
\end{tabular} & 19.9 & 6.8 & 63.7 & January & 22.5 & 6.6 & 55.3 \\
\hline February & 23.7 & 8.7 & 47.7 & February & 25.5 & 8.1 & 47.7 \\
\hline March & 26 & 9.7 & 43 & March & 28.2 & 9.7 & 43 \\
\hline April & 29.8 & 17.5 & 34.3 & April & 29.8 & 9.6 & 35.7 \\
\hline May & 34.4 & 18.7 & 33.0 & May & 36.6 & 19.1 & 27.3 \\
\hline
\end{tabular}

The following data were recorded:

Morphological characters:

Days to heading: were recorded as number of days period from sowing to the date when $50 \%$ of spikes completely emergence from the flag sheath, Days to maturity: number of the days from sowing to the date when $50 \%$ of the peduncles turned yellow, Plant height $(\mathbf{c m})$ : was measured as the 
distance between the base of the main Culm and the top of its spike excluding owns, Grain filling period: was recorded as the period from heading until days to maturity and Grain filling rate $=$ grain yield/grain filling period.

Yield and its components:

Number of spikes $/ \mathbf{m}^{2}$ : (no. of tillers bearing fertile spikes): was determined by counting the number of spikes in a square meter randomly taken from each plot, Number of kernels/spike: was determined on ten randomly selected spikes in each experimental plot, kernel weight (gm): was recorded as an average of three samples, of 1000-kernel in each plot taken at random and weighted and Grain yield (ardab/faddan): was estimated from the harvested area of each experimental plot and converted to ardab/faddan.

Statistical analysis: Randomized complete block design was followed in each location, then combined analysis was made between the two locations in each season to obtain the effect of location. After the two seasons combined analysis was followed to determine the effect of seasons according to Steel and Torrie (1980).

\section{RESULTS AND DISCUSSION}

\section{Morphological characters:}

Days to heading:

Days to heading were affected by environments through the two seasons (Table 2). There were deferent significant degrees between varieties through two seasons and tow locations. The lowest values were noticed in Sakha 93 the earliest variety in the two seasons in Sakha station and in Asouyt in the first season. Sids 12 and Gemmeiza 9 were the earliest varieties in Asouyt station in the second season. The increased in grain protein content caused by heat and drought stress after flowering may be associated with yield losses, due to a reduction in the starch production (Fowler 2003). The interaction had a significant difference between environments and genotypes, environments and growing seasons and environments and growing seasons. Wheat shows a highly significant degree genotype by environment interaction (GxE) (Reynolds et al., 2002). 
Table (2): Effect of environmental temperature on Days to heading of some bread wheat varieties in two growing seasons (2010/2011-2011/2012).

\begin{tabular}{|c|c|c|c|c|c|c|c|c|c|}
\hline \multirow{2}{*}{ Varieties } & \multicolumn{3}{|c|}{ Sakha station } & \multicolumn{3}{|c|}{ Asouyt station } & \multicolumn{3}{|c|}{ Overall } \\
\hline & S1 & S2 & Mean & S1 & S2 & Mean & S1 & S2 & Mean \\
\hline Sakha 93 & 88.67 & 90.67 & 89.67 & 85.67 & 101.67 & 93.67 & 87.17 & 96.17 & 91.67 \\
\hline Misr 1 & 94.00 & 96.00 & 95.00 & 87.67 & 100.67 & 94.17 & 90.83 & 98.33 & 94.59 \\
\hline $\begin{array}{l}\text { Gemmeiza } \\
9\end{array}$ & 95.33 & 97.33 & 96.33 & 88.00 & 96.67 & 92.34 & 91.67 & 97.00 & 94.33 \\
\hline Sids12 & 92.33 & 94.33 & 93.33 & 96.00 & 96.67 & 96.34 & 94.17 & 95.50 & 94.83 \\
\hline Mean & 92.58 & 94.58 & 93.58 & 89.33 & 98.92 & 94.13 & 90.96 & 96.75 & 93.86 \\
\hline CV\% & 2.60 & 2.58 & 2.59 & 3.31 & 2.50 & 2.95 & & & 2.75 \\
\hline $\begin{array}{l}\text { LSD } 0.05 \\
\text { V } \\
\text { S } \\
\text { VS } \\
\text { E } \\
\text { ES } \\
\text { V E } \\
\text { VS E }\end{array}$ & 1.10 & 1.10 & $\begin{array}{l}0.69 \\
0.33 \\
\text { NS }\end{array}$ & 2.33 & 0.45 & $\begin{array}{l}1.13 \\
0.87 \\
1.60\end{array}$ & & & $\begin{array}{l}0.65 \\
0.46 \\
0.92 \\
0.43 \\
0.61 \\
0.87 \\
1.22\end{array}$ \\
\hline
\end{tabular}

$\mathrm{V}=$ varieties, $\mathrm{S}=$ seasons, $\mathrm{E}=$ different environments

\section{Days to maturity:}

The days to maturity were significantly lower in Asouyt station than in Sakha at the first season. Misr1 was the earliest (lower days to mature) in the two environments in both seasons. Such phenomena could be illustrated as the temperature regulates many of the physiological and chemical processes within a plant, which in turn control the rate of growth and its development towards maturity (Khichar and Ram Niwas, 2007).

Table (3): Effect of environmental temperature on days to maturity of some bread wheat varieties in two growing seasons (2010/2011-2011/2012).

\begin{tabular}{|l|c|c|c|c|c|c|c|c|c|}
\hline \multirow{2}{*}{ Varieties } & \multicolumn{3}{|c|}{ Sakha station } & \multicolumn{3}{c|}{ Asouyt station } & \multicolumn{3}{c|}{ Overall } \\
\cline { 2 - 11 } & S1 & S2 & Mean & S1 & S2 & Mean & S1 & S2 & Mean \\
\hline Sakha 93 & 141.67 & 144.33 & 143.00 & 131.00 & 140.67 & 135.84 & 136.33 & 142.50 & 139.42 \\
\hline Misr 1 & 140.67 & 143.67 & 142.17 & 130.67 & 138.33 & 134.50 & 135.67 & 141.00 & 138.34 \\
\hline Gemmeiza 9 & 143.67 & 146.67 & 145.17 & 133.00 & 143.67 & 138.34 & 138.33 & 145.17 & 141.75 \\
\hline Sids12 & 141.67 & 144.67 & 143.17 & 137.33 & 143.67 & 140.50 & 139.50 & 144.17 & 141.84 \\
\hline Mean & 141.92 & 144.83 & 143.38 & 133.00 & 141.58 & 137.29 & 137.46 & 143.21 & 140.34 \\
\hline CV\% & 2.61 & 2.45 & 2.53 & 3.59 & 2.35 & 3.12 & & & 2.9 \\
\hline LSD 0.05 & & & & & & & & & \\
V & 1.73 & 1.29 & 0.96 & 4.23 & 1.00 & 1.93 & & & 1.02 \\
S & & & 0.87 & & & 0.40 & & & 0.72 \\
VS & & & NS & & & NS & & & NS \\
E & & & & & & & & & 0.78 \\
ES & & & & & & & & & 1.10 \\
V E & & & & & & & & & 1.55 \\
VS E & & & & & & & & & \\
\hline
\end{tabular}

$\mathrm{V}=\mathrm{varieties}, \mathrm{S}=$ seasons, $\mathrm{E}=$ different environments 
On the other hand, there is substantial scope for improvement in productivity under unfavorable environments that are characterized by a significant presence of abiotic stresses such as high temperature (Joshi et al., 2007). There was a significant difference in the interaction between environments and varieties through two seasons as detected in Table (3). Plant requires energy to grow and develop and some of this energy is available in the form of heat. The required heat is expressed as degree of temperature. Plant responds to dominant climatic factors like temperature and sunshine hours (Khichar and Ram Niwas, 2007).

\section{Grain filling period:}

Through two seasons, grain filling period of all the tested varieties was lower in Asouyt environments than in Sakha environments. There were varied significant differences among varieties through two seasons in the two environments and Misr1 was the lowest (Table 4). On contrary, there was no significant difference in the interaction between varieties and environments through two growing seasons. Protein accumulation also changes in response to stress. Such results were agreed with Hunt et al., (1991) who reported that temperatures during early crop development and particularly high temperatures after anthesis may limit yield. Temperature fluctuations during grain filling were found to lower the proteins that play an active role in the biosynthesis and metabolism, storage proteins and those involved in protecting the plants against biotic and abiotic stresses are accumulated preferentially. Specific protein responses depend on whether or not high temperature occurs during the early or middle phases of grain-filling (Hurkman et al., 2009).

Table (4): Effect of environmental temperature on Grain filling period of some bread wheat varieties in two growing seasons (2010/2011-2011/2012).

\begin{tabular}{|c|c|c|c|c|c|c|c|c|c|}
\hline \multirow[t]{2}{*}{ Varieties } & \multicolumn{3}{|c|}{ Sakha station } & \multicolumn{3}{|c|}{ Asouyt station } & \multicolumn{3}{|c|}{ Overall } \\
\hline & S1 & S2 & Mean & S1 & $\mathrm{S2}$ & Mean & S1 & S2 & Mean \\
\hline Sakha 93 & 53.00 & 53.67 & 53.33 & 39.00 & 45.33 & 42.17 & 46.00 & 49.50 & 47.75 \\
\hline Misr 1 & 46.667 & 47.67 & 47.17 & 37.67 & 43.00 & 40.33 & 42.17 & 45.33 & 43.75 \\
\hline Gemmeiza 9 & 48.33 & 49.33 & 48.83 & 47.00 & 45.00 & 46.00 & 47.67 & 47.17 & 47.42 \\
\hline Sids12 & 49.33 & 50.33 & 49.83 & 44.00 & 41.33 & 42.67 & 46.67 & 45.83 & 46.25 \\
\hline Mean & 49.33 & 50.25 & 49.79 & 41.92 & 43.67 & 42.79 & 45.63 & 46.96 & 46.29 \\
\hline CV\% & 4.24 & 3.85 & 4.05 & 4.07 & 5.64 & 4.99 & & & 3.96 \\
\hline \begin{tabular}{|l} 
LSD0.05 \\
V \\
S \\
VS \\
E \\
ES \\
V E \\
VS E
\end{tabular} & 2.21 & 1.85 & $\begin{array}{l}1.28 \\
\text { NS } \\
\text { NS }\end{array}$ & 1.73 & NS & $\begin{array}{l}1.61 \\
0.87 \\
2.28\end{array}$ & & & $\begin{array}{c}0.87 \\
\text { NS } \\
1.24 \\
0.75 \\
1.06 \\
1.50 \\
2.12\end{array}$ \\
\hline
\end{tabular}

\section{Grain filling rate:}

Terminal or late heat stress especially during anthesis and grain filling stage of the late planted wheat is considered one of the major environmental factors drastically reducing wheat production (Irfaq et al., 
2005). The grain-filling rate was more temperature-sensitive than days to anthesis and duration of grain-filling. Effect of earliness on the yield under high temperature was highly dependent on the temperature regime during the heading stage Zhong-hu \& Rajaram (1994). The present study showed that grain filling rate was lower in all the tested varieties at Upper Egypt (Asouyt environment) than Sakha environments in the second season. The variation was significant in case of Sakha station in the two seasons, while it was significant only in the first season in case of Asouyt environment. The greatest grain filling rate in Sakha environments was in Misr 1 variety followed by Gemmeiza 9, Sids 12 and Sakha 93, respectively. The highest value was at Asouyt in Misr 1 variety in the first season and in Sids 12 variety in the second season (Table 5). The interaction between varieties and environments showed significant differences through the two growing seasons.

Table (5): Effect of environmental temperature on Grain filling rate of some bread wheat varieties in two growing seasons (2010/2011-2011/2012).

\begin{tabular}{|c|c|c|c|c|c|c|c|c|c|}
\hline \multirow{2}{*}{ Varieties } & \multicolumn{3}{|c|}{ Sakha station } & \multicolumn{3}{|c|}{ Asouyt station } & \multicolumn{3}{|c|}{ Overall } \\
\hline & S1 & S2 & Mean & S1 & S2 & Mean & S1 & S2 & Mean \\
\hline Sakha 93 & 0.14 & 0.51 & 0.33 & 0.25 & 0.40 & 0.33 & 0.20 & 0.46 & 0.33 \\
\hline Misr 1 & 0.20 & 0.68 & 0.44 & 0.37 & 0.46 & 0.42 & 0.29 & 0.57 & 0.43 \\
\hline Gemmeiza 9 & 0.19 & 0.57 & 0.38 & 0.27 & 0.36 & 0.32 & 0.23 & 0.46 & 0.35 \\
\hline Sids12 & 0.17 & 0.56 & 0.37 & 0.31 & 0.48 & 0.40 & 0.24 & 0.52 & 0.38 \\
\hline Mean & 0.18 & 0.58 & 0.38 & 0.30 & 0.43 & 0.36 & 0.24 & 0.50 & 0.37 \\
\hline CV\% & 8.99 & 5.72 & 6.87 & 6.87 & 5.46 & 6.05 & & & 6.13 \\
\hline $\begin{array}{l}\text { LSD0.05 } \\
\text { V } \\
\text { S } \\
\text { VS } \\
\text { E } \\
\text { ES } \\
\text { VE } \\
\text { VS E }\end{array}$ & 0.03 & 0.07 & $\begin{array}{l}0.03 \\
0.01 \\
0.05\end{array}$ & 0.04 & 0.05 & $\begin{array}{l}0.03 \\
0.04 \\
0.04\end{array}$ & & & $\begin{array}{c}0.02 \\
0.01 \\
N S \\
N S \\
0.02 \\
0.03 \\
0.05\end{array}$ \\
\hline
\end{tabular}

\section{Plant height:}

Data in table (6) showed that, environment conditions had significantly affected the plant height. A significant reduction in plant height of all the tested varieties at Upper Egypt (Asouyt) was detected compared to Nouth Egypt (Sakha). There was a significant difference between varieties; Gemmieza 9 was the tallest in Sakha environments through the two growing seasons, while Sids 12 was the tallest in Asouyt through the two seasons. The interaction between varieties and environments showed a significant difference through the two growing seasons. Such results confirmed the article that delayed planting reduced the plant height, days to heading, days to maturity and grain filling duration and ultimately showed the reduction in yield and yield components as reported by Din and Singh (2005) and Mahboob et al., (2005). 
Table (6): Effect of environmental temperature on Plant height/cm of some bread wheat varieties in two growing seasons (2010/2011-2011/2012).

\begin{tabular}{|c|c|c|c|c|c|c|c|c|c|}
\hline \multirow{2}{*}{ Varieties } & \multicolumn{3}{|c|}{ Sakha station } & \multicolumn{3}{|c|}{ Asouyt station } & \multicolumn{3}{|c|}{ Overall } \\
\hline & S1 & S2 & Mean & S1 & S2 & Mean & S1 & S2 & Mean \\
\hline Sakha 93 & 106.67 & 111.67 & 109.17 & 85.00 & 88.33 & 86.67 & 95.83 & 100.00 & 97.92 \\
\hline Misr 1 & 115.00 & 120.00 & 117.50 & 86.67 & 96.67 & 91.67 & 100.83 & 108.33 & 104.58 \\
\hline Gemmeiza 9 & 121.67 & 126.67 & 124.17 & 85.00 & 103.3 & 94.17 & 103.33 & 115.00 & 109.17 \\
\hline Sids12 & 110.00 & 115.00 & 112.50 & 100.0 & 103.3 & 101.67 & 105.00 & 109.17 & 107.08 \\
\hline Mean & 113.33 & 118.33 & 115.83 & 89.17 & 97.92 & 93.54 & 101.25 & 108.13 & 104.69 \\
\hline CV\% & $5.95 \%$ & 3.86 & 3.90 & 3.62 & 4.95 & 4.44 & & & 3.81 \\
\hline $\begin{array}{l}\text { LSD0.05 } \\
\text { V } \\
\text { S } \\
\text { VS } \\
\text { E } \\
\text { ES } \\
\text { VE } \\
\text { VSE }\end{array}$ & 4.40 & 4.40 & $\begin{array}{c}2.77 \\
1.80 \\
\text { NS }\end{array}$ & 2.88 & 5.77 & $\begin{array}{l}2.87 \\
2.59 \\
4.06\end{array}$ & & & $\begin{array}{l}2.10 \\
1.45 \\
2.97 \\
1.17 \\
1.65 \\
2.34 \\
1.10\end{array}$ \\
\hline
\end{tabular}

$\mathrm{V}=\mathrm{varieties}, \mathrm{S}=$ seasons, $\mathrm{E}=$ different environments

\section{Yield and its components} Grain yield (Ard/fad):

The results in Table (7) showed the effect of different environments on grain yield ( $\mathrm{ard} / \mathrm{fad}$ ) of bread wheat cultivars during the two growing seasons. Different environments had a significant effect on grain yield (ard/fad) at the two growing season. The highest grain yield was obtained in all varieties cultivated at Sakha environment. There was a significant difference among the varieties through the two growing season, Misr1 gave the highest grain yield in both location through the two growing seasons. Environments and varieties interaction had a significant effect on grain yield at the two growing season.

Table (7): Effect of environmental temperature on Grain yield Ardab/faddan of some bread wheat varieties in two growing seasons (2010/2011-2011/2012).

\begin{tabular}{|l|c|c|c|c|c|c|c|c|c|}
\hline Varieties & \multicolumn{3}{|c|}{ Sakha station } & \multicolumn{3}{c|}{ Asouyt station } & \multicolumn{3}{c|}{ Overall } \\
\cline { 2 - 11 } & S1 & S2 & Mean & S1 & S2 & Mean & S1 & S2 & Mean \\
\hline Sakha 93 & 27.71 & 27.12 & 27.42 & 9.82 & 18.29 & 14.05 & 18.76 & 22.71 & 20.74 \\
\hline Misr 1 & 29.36 & 31.75 & 30.56 & 14.05 & 19.90 & 16.98 & 21.71 & 25.82 & 23.77 \\
\hline Gemmeiza 9 & 29.38 & 27.41 & 28.40 & 12.50 & 16.25 & 14.38 & 20.94 & 21.83 & 21.39 \\
\hline Sids12 & 28.73 & 27.55 & 28.14 & 13.61 & 19.90 & 16.75 & 21.14 & 23.72 & 22.45 \\
\hline Mean & 28.80 & 28.46 & 28.63 & 12.49 & 18.58 & 15.54 & 20.64 & 23.53 & 22.08 \\
\hline CV\% & 4.8 & 6.86 & 5.96 & 6.91 & 5.45 & 6.04 & & & 6.94 \\
\hline LSD0.05 & & & & & & & & & \\
V & \multirow{2}{*}{2.77} & 1.39 & 1.23 & 1.28 & 0.79 & & & 0.85 \\
S & & & NS & & & 1.49 & & & 0.60 \\
VS & & & 1.97 & & & 1.12 & & & 1.21 \\
E & & & & & & & & 0.58 \\
ES & & & & & & & & 1.82 \\
VE & & & & & & & & & \\
VSE & & & & & & & & & \\
\hline
\end{tabular}


The results in Table (7) also cleared that growing seasons, VS, ES, EV and VSE interaction had significant effects on grain yield. The factors affecting productivity of any region is climate and its principal weather componentsrainfall, temperature and solar radiation (Khichar and Ram Niwas, 2007).

Different environments had a significant effect on grain yield (ard/fad) at the two growing season. The highest grain yield was obtained in all varieties cultivated at Sakha environment. There was a significant difference among the varieties through the two growing season, Misr1 gave the highest grain yield in both location through the two growing seasons. Environments and varieties interaction had a significant effect on grain yield at the two growing season. The results in Table (7) also cleared that growing seasons, VS, ES, EV and VSE interaction had significant effects on grain yield. The factors affecting productivity of any region is climate and its principal weather components- rainfall, temperature and solar radiation (Khichar and Ram Niwas, 2007). With delayed planting, the development of plant organs and transfer from source to sink were remarkably affected. It was reflected by overall shortening of plant height, reduction in number of internodes, days to heading, days to maturity and grain filling period and ultimately in the reduction of yield and yield components (Mahboob et al., 2005). Reduction in grain yield may be attributed to effect on delayed germination, decreasing number of days to $50 \%$ flowering, maturity and increasing grain filling period and the different in yield components can result from differences in ability of cultivars to produce more values and sustain yield component characters (Nyamudeza and Mutema, 2002)

Number of spikes $/ \mathrm{m}^{2}$ :

Table (8): Effect of environmental temperature on number of spikes $/ \mathrm{m}^{2}$ of some bread wheat varieties in two growing seasons (2010/2011-2011/2012).

\begin{tabular}{|c|c|c|c|c|c|c|c|c|c|}
\hline \multirow{2}{*}{ Varieties } & \multicolumn{3}{|c|}{ Sakha station } & \multicolumn{3}{|c|}{ Asouyt station } & \multicolumn{3}{|c|}{ Overall } \\
\hline & S1 & S2 & Mean & S1 & S2 & Mean & S1 & S2 & Mean \\
\hline Sakha 93 & 399.33 & 412.33 & 405.83 & 245.33 & 334.00 & 289.67 & 322.33 & 373.17 & 347.75 \\
\hline Misr 1 & 386.00 & 399.00 & 392.50 & 235.00 & 355.33 & 295.17 & 310.50 & 377.17 & 343.83 \\
\hline Gemmeiza 9 & 349.33 & 362.33 & 355.83 & 265.67 & 423.33 & 344.50 & 307.50 & 392.83 & 350.17 \\
\hline Sids12 & 484.33 & 497.33 & 490.83 & 240.33 & 365.67 & 303.00 & 362.33 & 431.50 & 396.92 \\
\hline Mean & 404.75 & 417.75 & 411.25 & 246.58 & 369.58 & 308.08 & 325.67 & 393.67 & 359.67 \\
\hline CV\% & 3.47 & 13.39 & 3.43 & 4.14 & 5.26 & 5.02 & & & 6.59 \\
\hline \begin{tabular}{|l} 
LSD0.05 \\
V \\
S \\
VS \\
E \\
ES \\
V E \\
VS E
\end{tabular} & 11.89 & 11.61 & $\begin{array}{l}7.40 \\
\text { NS } \\
\text { NS }\end{array}$ & 10.54 & 24.07 & $\begin{array}{c}11.70 \\
7.65 \\
16.54\end{array}$ & & & $\begin{array}{c}7.92 \\
5.60 \\
11.20 \\
5.26 \\
8.41 \\
10.52 \\
14.87\end{array}$ \\
\hline
\end{tabular}

The deferent environments had a significant effect on number of spikes $/ \mathrm{m}^{2}$ at the two growing seasons (Table 8). The highest no. of spikes $/ \mathrm{m}^{2}$ was obtained under Sakha environment in the both seasons. There was a significant difference between the varieties for number of spikes $/ \mathrm{m}^{2}$. Sids 12 
was the highest significant number of spike $/ \mathrm{m}^{2}$ in Sakha at the two growing seasons. Gemmeiza9 gave the highest significant number of spike $/ \mathrm{m}^{2}$ in Asuit through the two growing seasons. In the two growing seasons, VS, ES, VE and VSE interactions had significant effect on number of spike/ $\mathrm{m}^{2}$. These results were agreed with those obtained by Mahboob et al., 2005 and Irfaq et al., 2005.

Number of kernels/spike:

Number of kernels/spike at the two growing seasons (Table 9) were significantly affected by the different environments. The highest number of kernels/spikes was obtained in Sakha environment at the two growing seasons. There was a significant difference between the varieties for number of kernels/spike at the two growing seasons. Misr1 gave the highest significant number of kernels/spike at the two growing seasons at Sakha. In Asuit, Sides 12 was the highest number of kernels/spike in the first season, while Misr1 gave the highest value in the second season. The interaction effect of, VS, ES, VE and VSE had significant effect on number of kernels/spike. The effect of late heat stress on yield and other growth parameters include shorter life cycle, reduced number of grains/spike, lower grain weight and reduced grain yield (Irfaq et al., 2005).

Table (9): Effect of environmental temperature on number of Kernels/spike of some bread wheat varieties in two growing seasons (2010/2011-2011/2012).

\begin{tabular}{|l|c|c|c|c|c|c|c|c|c|}
\hline \multirow{2}{*}{ Varieties } & \multicolumn{3}{c|}{ Sakha station } & \multicolumn{2}{c|}{ Asouyt station } & \multicolumn{3}{c|}{ Overall } \\
\cline { 2 - 11 } & S1 & S2 & Mean & S1 & S2 & Mean & S1 & S2 & Mean \\
\hline Sakha 93 & 63.33 & 65.63 & 64.48 & 54.33 & 61.00 & 57.67 & 58.83 & 63.32 & 61.07 \\
\hline Misr 1 & 84.67 & 86.97 & 85.82 & 65.00 & 81.00 & 73.00 & 74.83 & 83.98 & 79.41 \\
\hline Gemmeiza 9 & 62.67 & 64.97 & 63.82 & 57.00 & 69.00 & 63.00 & 59.83 & 66.98 & 63.41 \\
\hline Sids12 & 65.00 & 67.30 & 66.15 & 72.33 & 66.00 & 69.17 & 68.67 & 66.65 & 67.66 \\
\hline Mean & 68.92 & 71.22 & 70.07 & 62.17 & 69.25 & 65.71 & 65.54 & 70.20 & 67.89 \\
\hline CV\% & 3.16 & 7.73 & 6.19 & 7.46 & 3.50 & 5.82 & & & 5.49 \\
\hline LSD0.05 & & & & & & & & & \\
V & 1.60 & 8.15 & 3.61 & 6.78 & 2.08 & 3.16 & & & 2.46 \\
S & & & 2.43 & & & 2.76 & & & 1.74 \\
VS & & & & & & 4.47 & & & 3.48 \\
E & & & & & & & & & 1.60 \\
ES & & & & & & & & & 3.27 \\
V E & & & & & & & & & 4.54 \\
VS E & & & & & & & & & \\
\hline
\end{tabular}

V=varieties, $\mathrm{S}=$ seasons, $\mathrm{E}=$ different environments

\section{Kernels weight}

Deferent environments had significant impact on 1000 kernels weight at the two growing seasons (Table 10). 
Table (10): Effect of environmental temperature on 1000 kernels weight of some bread wheat varieties in two growing seasons (2010/2011-2011/2012).

\begin{tabular}{|l|c|c|c|c|c|c|c|c|c|}
\hline \multirow{2}{*}{ Varieties } & \multicolumn{3}{|c|}{ Sakha station } & \multicolumn{2}{c|}{ Asouyt station } & \multicolumn{3}{c|}{ Overall } \\
\cline { 2 - 11 } & S1 & S2 & Mean & S1 & S2 & Mean & S1 & S2 & Mean \\
\hline Sakha 93 & 49.580 & 51.460 & 50.520 & 37.150 & 40.747 & 38.949 & 43.365 & 46.104 & 44.735 \\
\hline Misr 1 & 56.617 & 58.497 & 57.557 & 34.893 & 37.850 & 36.372 & 45.755 & 48.174 & 46.964 \\
\hline Gemmeiza 9 & 54.443 & 56.323 & 55.383 & 40.320 & 40.067 & 40.194 & 47.380 & 48.195 & 47.788 \\
\hline Sids12 & 52.843 & 54.723 & 53.783 & 38.773 & 41.310 & 40.042 & 45.808 & 48.017 & 46.912 \\
\hline Mean & 53.371 & 55.251 & 54.311 & 37.784 & 39.993 & 38.889 & 45.577 & 47.623 & 46.600 \\
\hline CV\% & 4.34 & 4.79 & 4.58 & 4.79 & 3.75 & 4.30 & & & 3.93 \\
\hline LSD0.05 & & & & & & & & & \\
V & 2.50 & 3.08 & 2.50 & 2.11 & 1.40 & 1.13 & & & 0.93 \\
S & & & 1.48 & & & 0.53 & & & NS \\
VS & & & NS & & & 1.59 & & & NS \\
E & & & & & & & & & 0.74 \\
ES & & & & & & & & & 1.04 \\
V E & & & & & & & & & NS \\
VS E & & & & & & & & & \\
VS
\end{tabular}

$\mathrm{V}=\mathrm{varieties}, \mathrm{S}=$ seasons, $\mathrm{E}=$ different environments

The highest values of kernels weight were recorded under Sakha environment at the two growing seasons. This result was agreed with Refay (2011). Therefore, the current study suggested to utilize the late planting conditions, grain filling duration, tillers $/ \mathrm{m}^{2}$, grains per spike, 1000 -grain weight and grain yield per plot would serve as valuable selection criteria, Ali et al., (2008). grain weight has been shown as the main yield component for $20 \%$ of variation in wheat grain yield Moghaddam et al (1998). Grain yield is a good indicator to estimate the impact of environmental temperatures on the wheat productivities, tolerant and characteristics. The recommendations of the present research is, also extended to study the rheological, chemical and sensory specified conditions.

\section{REFERENCES}

Ali, Y., B.M. Atta, J. Akhter, P. Monneveux and Z. Lateef (2008). Genetic variability, association and diversity studies in wheat (Triticum aesitum L.) germplasm. Pak. J. Bot., 40(5): 2087-2097.

Balla K., M. Rakszegi, Z. Li, F. Bekes, S. Bencze, O. Veisz (2011). Quality of winter wheat in relation to heat and drought shock after anthesis. Czech J. Food Sci., 29: 117-128.

Balla K. and O.Veisz (2007). Changes in the quality of cereals in response to heat and drought stress. Acta Agronomica Ovariensis, 49: 451-455.

Bencze S., O.Veisz and Z. Bedő (2004). Effects of high atmospheric CO2 and heat stress on phytomass, yield and grain quality of winter wheat. Cereal Research Communications,32: 75-82.

Blumenthal C.S., I.L Batey., F. Bekes, C.W. Wrigley, E.W.R. Barlow (1991). Seasonal changes in wheat-grain quality associated with high temperatures during grain filling. Australian Journal of Agricultural Research, 42:21-30. 
Corbellini M., M.G. Canevar, L. Mazza, M. Ciaffi, D. Lafiandra and B. Borghi (1997). Effect of the duration and intensity of heat shock during grain filling on dry matter and protein accumulation, technological quality and protein composition in bread and durum wheat. Aust. J. Plant Physiol. 24, 245-260.

Din K. and R.M. Singh (2005). Grain filling duration: An important trait in wheat improvement. SAIC Newsletter, 15(4): 4-5.

Fowler D.B. (2003). Crop nitrogen demand and grain protein concentration of spring and winter wheat. Agronomy Journal, 95: 260-265.

Hunt L.A., G. van der Poorten and S. Pararajasingham (1991). Postanthesis temperature effects on duration and rate of grain filling in some winter and spring wheats. Can J Plant Sci 71: 609-617.

Hurkman W.J., W.H. Vensel, C.K. Tanaka, L. Whitehand, S.B. Altenbach (2009). Effect of high temperature on albumin and globulin accumulation in the endosperm proteome of the developing wheat grain. Journal of Cereal Science, 49: 12-23.

Irfaq M., T. Muhammad, M. Amin, and A. Jabbar (2005). Performance of yield and other agronomic characters four wheat (Triticum aestivum L.) genotypes under natural heat stress. Intl. J. Bot., 1(2):124-124.

Joshi A.K., B. Mishra, R. Chatrath, R. Ortiz Ferrara and R.P. Singh (2007). Wheat improvement in India: Present status, emerging challenges, and future prospects, Euphytica 10:681-685.

Khichar M.L. and R. Niwas (2007). Thermal effect on growth and yield of wheat under different sowing environments and planting system. Indian J. Agric. Res., 41 (2) : 92 - 96.

Kumari V., S. Shah and M.N. Gupta (2007). Preparation of Biodiesel by Lipase-Catalyzed Transesterification of High Free Fatty Acid Containing Oil from Madhucaindica, Energy Fuels 21:368-372.

Labuschagne M.T., O. Elago and E. Koen (2009). The influence of temperature extremes on some quality and starch characteristics in bread, biscuit and durum wheat. Journalof Cereal Science, 49: 184189.

Mahboob A.S., M.A. Arain, S. Khanzada, M.H. Naqvi, M.U. Dahot and N.A. Nizamani (2005). Yield and quality parameters of wheat genotypes as affected by sowing dates and high temperature stress. Pak. J. Bot., 37(3):575-584.

Moghaddam M., B. Ehdaie, and J.G. Waines (1998). Genetic variation for and interrelationships among agronomic traits in landraces of bread wheat from southwestern Iran. Journal of Genetics and Breeding. 52(1):73-81.

Mohammadi M., R.A. Karimizadeh and M.R. Naghavi (2009). Selection of bread wheat genotypes against heat and drought tolerance on the base of chlorophyll content and stem reserves. J. Agric. Soc. Sci., 5: 119-122.

Nyamudeza P. and Z. Mutema (2002). Wheat sowing date trials. Lowveld Research Station Review and Planning Workshp. 22 August Chirezi research Station, p. o. Box 97, chiredzi, Zimbawe. 
Refay Y. A. (2011). Yield and yield component parameters of bread wheat genotypes as affected by sowing dates. Middle-East Journal of Scientific Research. 7 (4):484-489.

Reynolds M.P., Trethowan R., Crossa J., Vargas M., Sayre K.D. (2002). Physiological factors associated with genotype by environment interaction in wheat. Field Crops Res. 75: 139-160.

Savin R., P.J. Stone and M.E. Nicolas (1996). Response of grain growth and malting quality of barley to short periods of high temperature in field studies using portable chambers. Aust. J. Agric. Res., 47: 465-477.

Steele R. G. and J. H. Torrie (1980). Principles and procedures of statistics. MC Graw Hill Book Co., New York.

Wardlaw I.F. and C.W. Wrigley (1994). Heat tolerance in temperate cereals. An overview. Aust. J. Plant Physiol., 21: 695-703.

Zhong-hu He and S. Rajaram (1994). Differential responses of bread wheat characters to high temperature Euphytica 72: 197-203.

$$
\begin{aligned}
& \text { تأثير إجهاد البيئة الحرارية على انتاجية وخصائص جودة الخبز لبعض اصناف قـح } \\
& \text { الخبز } \\
& \text { I. تأثير إجهاد البيئة الحرارية علي المحصول ومكوناته لبعض اصناف قمح الخبز }
\end{aligned}
$$

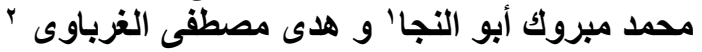

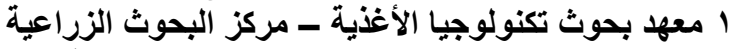

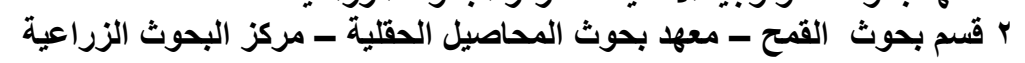

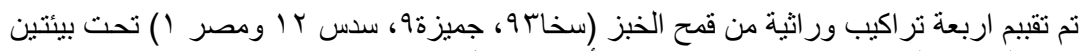

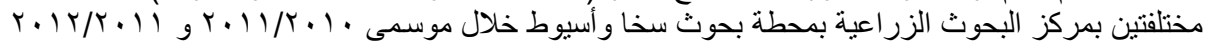

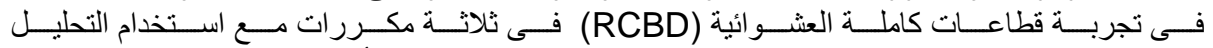

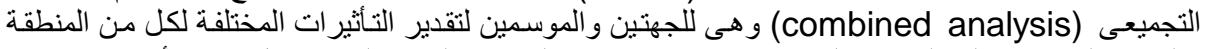

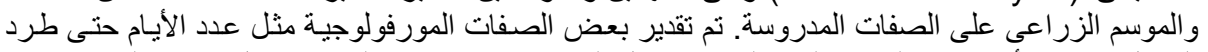

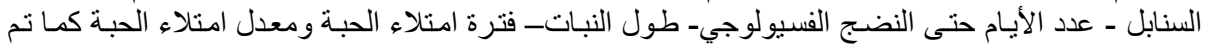

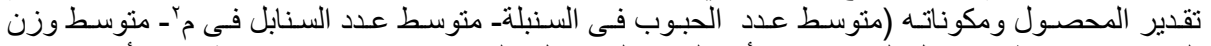

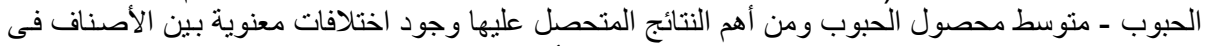

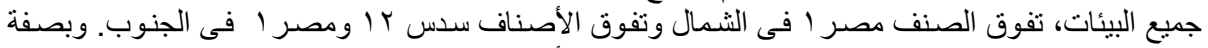

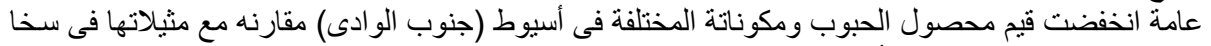

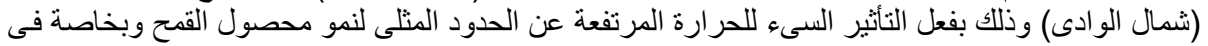

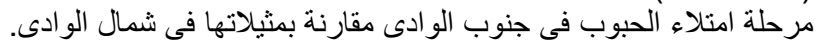

$$
\begin{aligned}
& \text { مركز البحوث الزراعية }
\end{aligned}
$$

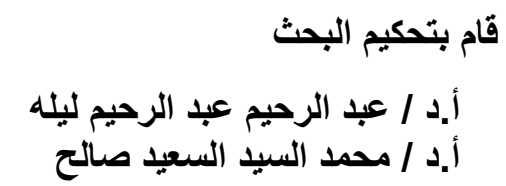


J. Plant Production, Mansoura Univ., Vol. 4 (10), October, 2013 